\title{
Implementasi Pembelajaran Direct Instruction Untuk Meningkatkan Pemahaman Pembelajaran Ilmu Pengetahuan Alam Materi Pencemaran Lingkungan danDampaknya bagi Kehidupan Pada Siswa Kelas VII.9 SMP Negeri 1 Praya Tahun Pelajaran 2018/2019
}

\author{
Baiq Nurkisnawati \\ Guru Mata Pelajaran IPA SMPN 1 Praya Lombok Tengah
}

\begin{abstract}
Abstrak. Permasalahan yang ingin dikaji dalam dalam penelitian tindakan ini adalah: (a) Apakah Metode Pembelajaran Direct Instruction berpengaruh terhadap kemampuan berbicara menggunakan Ilmu Pengetahuan Alam? (b) Bagaimanakah pengaruh Metode Pembelajaran Direct Instruction terhadap motivasi belajar Ilmu Pengetahuan Alam siswa? Tujuan penelitian yang hendak diperoleh adalah: (a) Untuk mengungkap pengaruh Metode Pembelajaran Direct Instruction terhadap kemampuan berbicara menggunakan Ilmu Pengetahuan Alam. (b) Untuk mengungkap Metode Pembelajaran Direct Instruction terhadap motivasi belajar Ilmu Pengetahuan Alam. Penelitian ini menggunakan penelitian tindakan (action research) sebanyak tiga putaran. Setiap putaran terdiri dari empat tahap yaitu: rancangan, kegiatan dan pengamatan, refleksi, dan refisi. Sasaran penelitian ini adalah siswa Kelas VII.9. Data yang diperoleh berupa hasil tes formatif, lembar observasi kegiatan belajar mengajar. Dari hasil analisis didapatkan bahwa prestasi belajar siswa mengalami peningkatan dari siklus I sampai siklus III yaitu, siklus I (73\%,), siklus II (83\%), siklus III (95\%). Simpulan dari penelitian ini adalah gabungan metode ceramah dengan kelompok kerja dapat berpengaruh positif terhadap prestasi dan motivasi belajar Siswa kelas VII.9, serta model pembelajaran ini dapat digunakan sebagai salah satu alternative pembelajaran Ilmu Pengetahuan Alam .
\end{abstract}

Kata kunci: Ilmu Pengetahuan Alam, Direct Instruction

PENDAHULUAN

Secara etimologis kata pembelajaran adalah terjemahan dari bahasa inggris yaitu "instruction". Kata tersebut merupakan perkembangan dari istilah belajar-mengajar atau proses belajar-mengajar yang digunakan dalam dunia pendidikan formal (sekolah). Perkembangan istilah pembelajaran diiringi juga dengan perkembangan cara pandang terhadap makna atau pardigma yang terkandung di dalamnya.

Pembelajaran adalah proses interaksi peserta didik dengan pendidik dan sumber belajar pada suatu lingkungan belajar. Pembelajaran merupakan bantuan yang diberikan pendidik agar dapat terjadi proses pemerolehan ilmu dan pengetahuan, penguasaan kemahiran dan tabiat, serta pembentukan sikap dan kepercayaan pada peserta didik. Dengan kata lain, pembelajaran adalah proses untuk membantu peserta didik agar dapat belajar dengan baik.
Proses pembelajaran dialami sepanjang hayat seorang manusia serta dapat berlaku di manapun dan kapanpun. Pembelajaran mempunyai pengertian yang mirip dengan pengajaran, walaupun mempunyai konotasi yang berbeda. Dalam konteks pendidikan, guru mengajar supaya peserta didik dapat belajar dan menguasai isi pelajaran hingga mencapai sesuatu objektif yang ditentukan (aspek kognitif), juga dapat mempengaruhi perubahan sikap (aspek afektif), serta keterampilan (aspek psikomotor) seseorang peserta didik. Pengajaran memberi kesan hanya sebagai pekerjaan satu pihak, yaitu pekerjaan guru saja. Sedangkan pembelajaran juga menyiratkan adanya interaksi antara guru dengan peserta didik.

Dari latar belakang masalah tersebut, maka penulis mengambil judul Implementasi Pembelajaran Direct Instruction Guna Meningkatkan Pemahaman Pembelajaran Ilmu Pengetahuan Alam Materi Pencemaran 
Lingkungan dan Dampaknya bagi Kehidupan Pada Siswa Kelas VII.9 SMP Negeri 1 Praya Tahun Pelajaran 2018/2019.

\section{Perumusan Masalah}

Merujuk pada uraian latar belakang di atas, dapat dikaji ada beberapa permasalahan yang dirumuskan sebagai berikut:

1. Apakah Metode Pembelajaran Direct Instruction berpengaruh terhadap kemampuan berbicara menggunakan Ilmu Pengetahuan Alam siswa Kelas VII.9 Tahun pelajaran 2018/2019?

2. Bagaimanakah pengaruh Metode Pembelajaran Direct Instruction terhadap motivasi belajar siswa Kelas VII.9 Tahun Pelajaran 2018/2019

\section{Tujuan Penelitian}

Berdasar atas perumusan masalah di atas, maka tujuan dilaksanakan penelitian ini adalah:

1. Ingin mengetahui pengaruh Metode Pembelajaran Direct Instruction terhadap kemampuan berbicara menggunakan Ilmu Pengetahuan Alam siswa Kelas VII.9 SMPN 1Praya

2. Ingin mengetahui efektifitas Metode Pembelajaran Direct Instruction dalam meningkatkan motivasi belajar Ilmu Pengetahuan Alam siswa Kelas VII.9 SMPN 1 Praya

\section{Manfaat Penelitian}

1. Bagi Guru: Guru-guru Ilmu Pengetahuan Alam perlu memanfaatkan teknik Metode Pembelajaran Direct Instruction untuk meningkatkan kualitas pembelajaran, baik dalam hal kualitas proses maupun kualitas hasil.

2. Bagi Siswa: Penelitian ini bermanfaat bagi siswa karena dapat meningkatkan dan mengoptimalkan kemampuan siswa dalam penerapan Metode Pembelajaran Direct Instruction dalam pembelajaran Ilmu Pengetahuan Alam.

3. Bagi Sekolah: Penelitian ini bermanfaat bagi sekolah sebagai referensi pembelajaran dan dinamisasi kegiatan belajar mengajar.

\section{KAJIAN TEORI}

\section{Model Pembelajaran Direct Instruction (Instruksi Langsung)}

Model pembelajaran Direct Instruction merupakan salah satu model pembelajaran kelompok sistem perilaku (behavior), prinsip yang dimiliki kelompok ini adalah bahwa manusia merupakan sistem-sistem komunikasi perbaikan diri (self-corecting communication systems) yang dapat mengubah perilakunya saat merespon informasi tentang seberapa sukses tugas-tugas yang mereka kerjakan. Teori belajar perilaku menekankan pada perubahan perilaku sebagai hasil belajar yang dapat diobservasi. Menurut teori ini, belajar bergantung pada pengalaman termasuk pemberian umpan balik dari lingkungan. Prinsip penggunaan teori perilaku ini dalam belajar adalah pemberian penguatan yang akan meningkatkan perilaku yang diharapkan. Penguatan melalui umpan balik kepada peserta didik merupakan dasar praktis penggunaan teori ini dalam pembelajaran.

Direct instruction dikembangkan oleh Tom Good, Jere Grophy, Carl Bereiter, Ziggy Engleman dan Wes Becker. Menurut Bruce Joyce (2009:421), beberapa keunggulan terpenting dari Direct Instruction ini adalah adanya fokus akademik, arahan dan kontrol instruktur, harapan yang tinggi terhadap perkembangan peserta didik, sistem manajemen waktu, dan atmosfer akademik yang cukup netral. Model Direct Instruction ini dirancang khusus untuk menunjang proses belajar peserta didik yang berkaitan dengan pengetahuan prosedural dan pengetahuan deklaratif yang terstruktur dengan baik, yang dapat diajarkan dengan pola kegiatan yang bertahap, selangkah demi selangkah. Dengan lima tahap aktivitas; yakni orientasi, presentasi, praktek yang terstruktur, praktik di bawah bimbingan dan praktik mandiri. Hal yang sama dikemukakan oleh Arends (1997:66) bahwa: "The direct instruction model was specifically designed to promote student learning of procedural knowledge and declarative knowledge that is well structured and can be taught in a step-by-step fashion."

Dua tujuan utama dari instruksi langsung adalah maksimalkan waktu belajar siswa dan mengembangkan kemandirian dalam mencapai dan mewujudkan tujuan pendidikan. Perilaku-perilaku guru yang 
tampak berhubungan dengan prestasi siswa sesungguhnya juga berhubungan dengan waktu yang dimiliki siswa dan rating kesuksesan mereka dalam mengerjakan tugas, yang pada gilirannya juga berhubungan erat dengan prestasi siswa. Oleh karena itulah, perilaku yang berkaitan erat dengan instruksi langsung memang dirancang untuk membuat sebuah lingkungan pendidikan yang berorientasi akademik dan juga terstruktur serta mengharuskan siswa untuk terlibat aktif (dalam tugas) saat pelaksanaan instruksi langsung. Siswa juga diharapkan dapat memperoleh rating kesuksesan yang cukup tinggi (sekitar 80 persen) dalam tugas yang diberikan.

Istilah instruksi langsung telah digunakan beberapa penelitian untuk merujuk pada suatu model pengajaran yang terdiri dari penjelasan guru mengenai konsep atau keterampilan baru terhadap siswa. Penjelasan ini dilanjutkan dengan meminta siswa menguji pemahaman mereka dengan mealakukan praktik dibawah bimbingan guru (praktik terkontrol, controlled practice), dan mendorong mereka meneruskan praktik di bawah bimbingan guru (praktik yang dibimbing, guide practice).

Model instruksi langsung terdiri dari lima tahap aktivitas; yakni orientasi, presentasi, praktik yang terstruktur, praktik di bawah bimbingan, dan praktik mandiri. Namun, penerapan model ini harus didahului oleh diagnosis yang efektif mengenai pengetahuan atau skill siswa untuk memastikan bahwa mereka memiliki pengetahuan dan skill untuk menapaki beberapa proses dan mampu mendapatkan level akurasi praktik dalam model ini.

Langkah-Langkah

Model

Pembelajaran Direct Instruction

Langkah-langkah pembelajaran pada model pembelajaran menurut Joyce, B., Weil, M., dan Calhoun, E. (2009:428) adalah sebagai berikut:

Tahap pertama adalah orientasi di mana kerangka kerja pelajaran dibangun. Selama tahap ini, guru menyampaikan harapan dan keinginannya, menjelaskan tugas-tugas yang ada dalam pembelajaran, dan menentukan tanggung jawab siswa. Ada tiga langkah yang sangat penting dalam meng-goal-kan tujuan tahap ini, yakni (1) guru memaparkan maksud dari pelajaran dan tingkat-tingkat performa dalam praktik guru menggambarkan isi pelajaran dan hubungannya dengan pengetahuan dan atau pengalaman sebelumnya; (3) guru mendiskusikan prosedur-prosedur pelajaran yakni bagian yang berbeda antara pelajaran dan tanggung jawab siswa selama aktivitasaktivitas ini berlangsung.

Tahap kedua adalah presentasi yakni menjelaskan konsep atau skill baru memberikan pemeragaan serta contoh. Jika materi yang ada merupakan konsep baru maka guru harus mendiskusikan karakteristikkarakteristik dari konsep tersebut, aturanaturan pendefinisian, dan beberapa contoh. Jika materinya adalah skill baru maka hal yang harus disampaikan guru adalah langkahlangkah untuk memiliki skill tersebut dengan menyajikan contoh di setiap langkah.

Tahap ketiga adalah praktik yang terstruktur. Guru menuntun siswa melalui contoh-contoh praktik dan langkah-langkah di dalamnya. Biasanya siswa melaksanakan praktek dalam sebuah kelompok, dan menawarkan dini untuk menulis jawaban.

Tahap keempat, praktik di bawah bimbingan guru, memberikan siswa kesempatan untuk melakukan praktik dengan kemauan mereka sendiri. Praktik di bawah bimbingan memudahkan guru mempersiapkan bantuan untuk mengembangkan kemampuan siswa dalam menampilkan tugas pembelajaran. Hal ini biasanya dilakukan dengan cara membantu mentinimalisir jumlah dan ragam kesalahan yang dilakukan siswa.

Pada tahap kelima, kita menuju praktik mandiri. Praktik ini dimulai saat siswa telah mencapai level akurasi 85 hingga 90 persen dalam praktik di bawah bimbingan. Tujuan dari praktik mandiri ini adalah memberikan materi baru untuk memastikan dan menguji pemahaman siswa terhadap praktik-praktik sebelumnya. Dalam praktik mandiri, siswa melakukan praktik dengan caranya sendiri tanpa bantuan dan respons balik dari guru. 


\section{Kelebihan dan Kekurangan Model Pembelajaran}

Kelemahan dari model pembelajaran disampaikan Arends (2009:314) bahwa "Kritik utama pada model ini adalah berpusat pada guru (teacher centered) dan terlalu menekankan teacher talk". Berdasarkan hasil studi pendahuluan yang penulis lakukan yaitu melakukan praktik terstruktur pada materi ajar penunjukan ukuran didapat kelemahan dari model pembelajaran ini, diantaranya:

a. Perlu adanya pengawasan lebih teliti dalam memberikan instruksi dalam pencantuman ukuran pada gambar, karena kemampuan setiap siswa dalam satu kelompok besar (kelas) berbeda-beda.

b. Perlengkapan untuk menggambar harus lengkap.

c. Guru sebelumnya harus mencoba melakukan prakikum untuk menyusun instruksi-instruksi yang akan diberikan pada siswa dan memprediksi poin-poin yang sulit. Hal ini menyebabkan waktu melakukan persiapan lebih lama.

Kelebihan dari model pembelajaran ini dijelaskan oleh beberapa ahli diantaranya:

1) Arends (2008:300) menjelaskan bahwa: "Model direct instruction dirancang secara spesifik untuk meningkatkan pembelajaran pengetahuan factual yang terstruktur dengan baik, yang dapat diajarkan secara selangkah dei selangkah dan dimaksudkan untuk membantu siswa menguasai pengetahuan procedural yang dibutuhkan untuk melakukan berbagai keterampilan sederhana maupun kompleks."

2) Model ini mendapatkan dukungan kuat dari hukum latihan (law of exercise) yang disampaikan oleh Thorndike dalam Sanjaya, W (2007:114) bahwa "hubungan stimulus dan repon akan semakin kuat manakala terus-menerus dilatih atau diulang."

3) Dengan periode praktik yang bertahap dapat mempercepat proses praktikum dan dengan waktu yang sama dengan model pembelajaran konvensional, pada model pembelajaran direct instruction dapat melakukan praktikum lebih banyak sehingga hasil belajar lebih baik. Seperti yang dijelaskan Joyce, B., Weil, M., dan Calhoun, E. (2009:426) bahwa: "periode yang singkat, intensif, dan dengan semangat yang tinggi akan menghasilkan pembelajaran yang lebih baik dibandingkan praktik yang sedikit dengan periode praktik yang lebih lama." d. Penerapan model ini dapat melatih kemandirian siswa. Sesuai dengan tujuan pembelajaran yang dijelaskan Joyce, B., Weil, M., dan Calhoun, E. (2009:422) bahwa "Dua tujuan utama dari instruksi langsung adalah memaksimalkan waktu belajar siswa dan mengembangkan kemandirian dalam mencapai dan mewujudkan tujuan pendidikan."

\section{Hasil Belajar}

Secara etimologis, maka penilaian diartikan sebagai proses menentukan nilai suatu objek, dan untuk dapat menentukan suatu nilai atau harga suatu objek diperlukan adanya ukuran atau kriteria. Sehingga ciri dari penilaian adalah adanya objek atau program yang dinilai dan adanya kriteria sebagai dasar untuk membandingkan antara kenyataan atau apa adanya dengan kriteria atau apa harusnya.

Nana Sudjana (2009:22) menyatakan bahwa "Hasil belajar adalah kemapuankemampuan yang dimiliki peserta didik setelah ia menerima pengalamaan belajarnya". Horward (Nana Sudjana, 2009:22) membagi tiga macam hasil belajar, yakni (a) keterampilan dan kebiasaan, (b) pengetahuan dan pengertian, dan (c) sikap dan cita-cita. Sedangkan, kegiatan belajar yang dilakukan peserta didik akan menghasilkan perubahan-perubahan pada dirinya yang oleh Bloom (Nana Sudjana, 2009:22) secara garis besar hasil belajar dikelompokkan kedalam ranah kognitif, afektif dan psikomotor. Hasilhasil yang diperoleh peserta didik dapat diukur atau diketahui berdasarkan perubahan perilaku sebelum dan sesudah dilakukan kegiatan belajar dalam bentuk prestasi belajar.

Hasil belajar adalah penguasaan pengetahuan atau keterampilan yang dikembangkan oleh mata pelajaran, lajimnya ditunjukkan dengan nilai test atau angka nilai yang diberikan oleh guru (KBBI,1999:787). 
Hasil belajar juga diartikan sebagai perubahan prilaku berupa pengetahuan, keterampilan, sikap, informasi dan atau strategi kognitif yang baru dan diperoleh peserta didik setelah berinteraksi dengan lingkungan dalam suatu suasana atau kondisi pembelajaran.

Hal ini, menunjukan bahwa hasil belajar merupakan perubahan tingkah laku individu secara sengaja yang dapat dievaluasi tinggi rendahnya sesuai dengan kriteria yang telah ditetapkan. Secara umum, Rudi Susilana (2006:102) menjelaskan bahwa "hasil belajar peserta didik dipengaruhi oleh faktor internal, yaitu faktor-faktor yang ada pada diri peserta didik dan faktor eksternal yaitu faktor yang berada diluar diri pelajar". Faktor-faktor tersebut dapat diuraikan sebagai berikut:

Materi Pembelajaran Pencemaran Lingkungan dan Dampaknya bagi Kehidupan Pengertian

Lingkungan diartikan sebagai suatu ruangan dengan segala objek, keadaan, kondisi maupun makhluk hidup termasuk manusia dan perilakunya yang saling mempengaruhi kelangsungan kehidupan dan kesejahteraan makhluk hidup lain. Menurut Ensiklopedia Kehutanan, lingkungan adalah jumlah total dari faktor-faktor non genetik yang mempengaruhi pertumbuhan dan reproduksi pohon, yang mencakup hal yang sangat luas, seperti tanah, kelembaban, cuaca, pengaruh hama dan penyakit, juga intervensi manusia.

Sedangkan pencemaran sendiri adalah peristiwa masuknya zat-zat ataupun komponen lain yang mengganggu keseimbangan lingkungan dan merugikan makhluk hidup dalam suatu ruang interaksi makhluk hidup untuk bertahan hidup (survive). Pencemaran lingkungan sendiri dapat disebabkan oleh kegiatan manusia ataupun proses alami. Pencemaran biasa disebut juga dengan polusi.

Sesuatu yang menyebabkan adanya polusi (pencemaran) sendiri disebut dengan polutan jika komponen tersebut melebihi batas normal dan berada pada ruang dan waktu yang tidak tepat. Adanya polutan tersebut, menyebabkan lingkungan menjadi kurang atau tidak sesuai dengan fungsinya.
Akibatnya, akan terjadi kerusakan lingkungan yang mengganggu dan merugikan makhluk hidup.

Macam - Macam Pencemaran

Pencemaran dapat bersumber dari pencemaran alami dan kegiatan manusia. Pencemaran alami adalah pencemaran dengan bahan yang berasal dari bencana alam, misalnya partikel gas atau debu yang berasal dari gunung meletus. Sedangkan pencemaran akibat kegiatan manusia, contohnya kegiatan industri yang menghasilkan limbah, transportasi, pertambangan, serta rumah tangga.

Pencemaran lingkungan sendiri terdapat banyak macam dan jenisnya. Jika dilihat dari sifat zat pencemarnya, dapat dibedakan menjadi tiga macam, yakni :1) Pencemaran biologis, 2) Pencemaran Fisik, 3)Pencemaran Kimiawi

Tabel 1. Komponen Udara Bersih Kering

\begin{tabular}{|c|c|c|}
\hline No. & Komponen Udara & Persentase \\
\hline 1. & Nitrogen & 78,09 \\
\hline 2. & Oksigen & 21,94 \\
\hline 3. & Argon & 0,93 \\
\hline 4. & Karbon Dioksida & 0,032 \\
\hline
\end{tabular}

Apabila terjadi pencemaran maka susunan udara berubah dari susunan keadaan normal. Hal ini akan mengganggu perikehidupan manusia, hewan dan makhluk hidup lainnya.

Pencemaran udara adalah pengotoran udara akibat masuknya bahan atau zat asing, energi dan komponen lainnya ke dalam udara. Hal itu dapat menyebabkan komposisi atmosfer abnormal. Pencemaran udara juga dapat diartikan sebagai adanya salah satu atau lebih komponen gas di udara dalam jumlah berlebihan. Pencemaran udara biasa terjadi di daerah perkotaan dan daerah industri.

$$
\text { Zat-zat pemcemar udara }
$$
umumnya berupa debu, asap dan gas buangan hasil pembakaran bahan bakar fosil, seperti minyak dan batu bara, oleh kendaraan bermotor dan mesin pabrik. Gas-gas tersebut sangat mengancam kesehatan manusia, sebab gas-gas tersebut mengandung zat berbahaya.

\section{METODE PENELITIAN}


Penelitian ini merupakan penelitian tindakan (action research), karena penelitian dilakukan untuk memecahkan masalah pembelajaran di kelas. Penelitian ini juga termasuk penelitian deskriptif, sebab menggambarkan bagaimana suatu teknik pembelajaran diterapkan dan bagaimana hasil yang diinginkan dapat dicapai.

Menurut Sukidin dkk (2002:54) ada 4 macam bentuk penelitian tindakan, yaitu: (1) penelitian tindakan guru sebagai peneliti, (2) penelitian tindakan kolaboratif, (3) penelitian tindakan simultan terintegratif, dan penelitian tindakan sosial eksperimental.

Keempat bentuk penelitian tindakan di atas, ada persamaan dan perbedaannya. Menurut Oja dan Smulyan sebagaimana dikutip oleh Kasbolah, (2000) (dalam Sukidin, dkk. 2002:55), ciri-ciri dari setiap penelitian tergantung pada: (1) tujuan utamanya atau pada tekanannya, (2) tingkat Metode Pembelajaran Direct Instruction antara pelaku peneliti dan peneliti dari luar, (3) proses yang digunakan dalam melakukan penelitian, dan (4) hubungan antara proyek dengan sekolah.

Dalam penelitian ini menggunakan bentuk guru sebagai peneliti, dimana guru sangat berperan sekali dalam proses penelitian tindakan kelas. Dalam bentuk ini, tujuan utama penelitian tindakan kelas ialah untuk meningkatkan praktik-praktik pembelajaran di kelas. Dalam kegiatan ini, guru terlibat langsung secara penuh dalam proses perencanaan, tindakan, observasi, dan refleksi. Kehadiran pihak lain dalam penelitian ini peranannya tidak dominan dan sangat kecil.

Penelitian ini mengacu pada perbaikan pembelajaran yang berkesinambungan. Kemmis dan Taggart (1988:14) menyatakan bahwa model penelitian tindakan adalah berbentuk spiral. Tahapan penelitian tindakan pada suatu siklus meliputi perencanaan atau pelaksanaan observasi dan refleksi. Siklus ini berlanjut dan akan dihentikan jika sesuai dengan kebutuhan dan dirasa sudah cukup.

\section{Tempat, Waktu dan Subyek Penelitian}

Penelitian ini bertempat di SMPN 1 Praya Tahun pelajaran 2018/2019, bulan Maret semester ganjil pada siswa-siswi Kelas
VII.9 tahun pelajaran 2018/2019 materi Pencemaran Lingkungan dan Dampaknya bagi Kehidupan

\section{Rancangan Penelitian}

Menurut pengertiannya penelitian tindakan adalah penelitian tentang hal-hal yang terjadi di masyarakat atau sekelompok sasaran, dan hasilnya langsung dapat dikenakan pada masyarakat yang bersangkutan (Arikunto, Suharsimi 2002:82). Ciri atau karakteristik utama dalam penelitian tindakan adalah adanya partisipasi dan Metode Pembelajaran Direct Instruction antara peneliti dengan anggota kelompok sasaran. Penelitian tindakan adalah satu strategi pemecahan masalah yang memanfaatkan tindakan nyata dalam bentuk proses pengembangan inovatif yang dicoba sambil jalan dalam mendeteksi dan memecahkan masalah. Dalam prosesnya pihak-pihak yang terlibat dalam kegiatan tersebut dapat saling mendukung satu sama lain. Sedangkan tujuan penelitian tindakan harus memenuhi beberapa prinsip sebagai berikut:

1. Permasalahan atau topik yang dipilih harus memenuhi kriteria, yaitu benarbenar nyata dan penting, menarik perhatian dan mampu ditangani serta dalam jangkauan kewenangan peneliti untuk melakukan perubahan.

2. Kegiatan penelitian, baik intervensi maupun pengamatan yang dilakukan tidak boleh sampai mengganggu atau menghambat kegiatan utama.

3. Jenis intervensi yang dicobakan harus efektif dan efisien, artinya terpilih dengan tepat sasaran dan tidak memboroskan waktu, dana dan tenaga.

4. Metodologi yang digunakan harus jelas, rinci, dan terbuka, setiap langkah dari tindakan dirumuskan dengan tegas sehingga orang yang berminat terhadap penelitian dapat mengecek setiap hipotesis dan pembuktiannya.

5. Kegiatan penelitian diharapkan dapat merupakan proses kegiatan yang berkelanjutan (on-going), mengingat bahwa pengembangan dan perbaikan terhadap kualitas tindakan memang 
tidak dapat berhenti tetapi menjadi tantangan sepanjang waktu. (Arikunto, Suharsimi, 2002:82-83).

Sesuai dengan jenis penelitian yang dipilih, yaitu penelitian tindakan, maka penelitian ini menggunakan model penelitian tindakan dari Kemmis dan Taggart (dalam Arikunto, Suharsimi, 2002:83), yaitu berbentuk spiral dari siklus yang satu ke siklus yang berikutnya. Setiap siklus meliputi planning (rencana), action (tindakan), observation (pengamatan), dan reflection (refleksi). Langkah pada siklus berikutnya adalah perencanaan yang sudah direvisi, tindakan, pengamatan, dan refleksi. Sebelum masuk pada siklus I dilakukan tindakan pendahuluan yang berupa identifikasi permasalahan. Siklus spiral dari tahap-tahap penelitian tindakan kelas dapat dilihat pada gambar berikut.

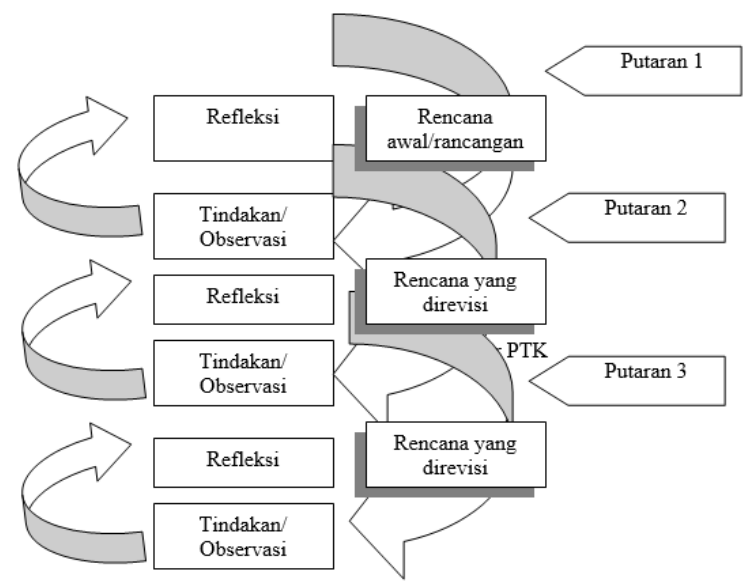

Gambar 3.1 Alur PTK

Observasi dibagi dalam tiga siklus, yaitu siklus 1, 2, dan seterusnya, dimana masing siklus dikenai perlakuan yang sama (alur kegiatan yang sama) dan membahas satu sub pokok bahasan yang diakhiri dengan tes formatif di akhir masing putaran. Siklus ini berkelanjutan dan akan dihentikan jika sesuai dengan kebutuhan dan dirasa sudah cukup.

\section{Alat Pengumpul Data}

Alat pengumpul data dalam penelitian ini adalah tes buatan guru yang fungsinya adalah: (1) untuk menentukan seberapa baik siswa telah menguasai bahan pelajaran yang diberikan dalam waktu tertentu, (2) untuk menentukan apakah suatu tujuan telah tercapai, dan (3) untuk memperoleh suatu nilai (Arikunto, Suharsimi,
2002:149). Sedangkan tujuan dari tes adalah untuk mengetahui ketuntasan belajar siswa secara individual maupun secara klasikal. Di samping itu untuk mengetahui letak kesalahan-kesalahan yang dilakukan siswa sehingga dapat dilihat dimana kelemahannya, khususnya pada bagian mana TPK yang belum tercapai. Untuk memperkuat data yang dikumpulkan maka juga digunakan metode observasi (pengamatan) yang dilakukan oleh teman sejawat untuk mengetahui dan merekam aktivitas guru dan siswa dalam proses belajar mengajar.

\section{Analisis Data}

Dalam rangka menyusun dan mengolah data yang terkumpul sehingga dapat menghasilkan suatu kesimpulan yang dapat dipertanggungjawabkan, maka digunakan analisis data kuantitatif dan pada metode observasi digunakan data kualitatif. Cara penghitungan untuk mengetahui ketuntasan belajar siswa dalam proses belajar mengajar sebagai berikut.

1. Merekapitulasi hasil tes

2. Menghitung jumlah skor yang tercapai dan prosentasenya untuk masingmasing siswa dengan menggunakan rumus ketuntasan belajar seperti yang terdapat dalam buku petunjuk teknis penilaian yaitu siswa dikatakan tuntas secara individual jika mendapatkan nilai minimal 65 , sedangkan secara klasikal dikatakan tuntas belajar jika jumlah siswa yang tuntas secara individu mencapai $85 \%$ yang telah mencapai daya serap lebih dari sama dengan $65 \%$.

3. Menganalisa hasil observasi yang dilakukan oleh guru sendiri selama kegiatan belajar mengajar berlangsung.

\section{HASIL DAN PEMBAHASAN Analisa data}

Suatu pokok bahasan atau sub pokok bahasan dianggap tuntas secara klasikal jika siswa yang mendapat nilai 65 lebih dari atau sama dengan $85 \%$, sedangkan seorang siswa dinyatakan tuntas belajar pada pokok bahasan atau sub pokok bahasan tertentu jika mendapat nilai minimal 65 . 


\section{Tahap Perencanaan}

Pada tahap ini peneliti mempersiapkan perangkat pembelajaran yang terdiri dari rencana pelajaran 1 , soal tes formatif 1 dan alat-alat pengajaran yang mendukung. Selain itu juga dipersiapkan lembar observasi pengelolaan model pembelajaran Metode Pembelajaran Direct Instruction, dan lembar observasi aktivitas guru dan siswa.

\section{Tahap Kegiatan dan Pelaksanaan}

Pelaksanaan kegiatan belajar mengajar untuk siklus I dilaksanakan pada tanggal 20 Maret 2019 di Kelas VII.9 jumlah siswa 32 siswa. Dalam hal ini peneliti bertindak sebagai pengajar. Adapun proses belajar mengajar mengacu pada rencana pelajaran yang telah dipersiapkan. Pengamatan (observasi) dilaksanakan bersamaan dengan pelaksanaan belajar mengajar.

Pada akhir proses belajar mengajar siswa diberi tes formatif I dengan tujuan untuk mengetahui tingkat keberhasilan siswa dalam proses belajar mengajar yang telah dilakukan. Adapun data hasil penelitian pada siklus I adalah sebagai berikut.

Berdasarkan hasil pengelolaan pembelajaran aspek-aspek yang mendapatkan kriteria kurang baik adalah memotivasi siswa, menyampaikan tujuan pembelajran, pengelolaan waktu, dan siswa antusias. Keempat aspek yang mendapat nilai kurang baik di atas, merupakan suatu kelemahan yang terjadi pada siklus I dan akan dijadikan bahan kajian untuk refleksi dan revisi yang akan dilakukan pada siklus II.

Dari hasil evaluasi dapat dijelaskan bahwa dengan menerapkan pembelajaran dengan Direct Instruction diperoleh nilai ratarata prestasi belajar siswa adalah 72 dan ketuntasan belajar mencapai $73 \%$ atau ada 24 siswa dari 32 siswa sudah tuntas belajar. Hasil tersebut menunjukkan bahwa pada siklus pertama secara klasikal siswa belum tuntas belajar, karena siswa yang memperoleh nilai $\geq 65$ hanya sebesar $71 \%$ lebih kecil dari persentase ketuntasan yang dikehendaki yaitu sebesar $85 \%$. Hal ini disebabkan karena siswa masih merasa baru dan belum mengerti apa yang dimaksudkan dan digunakan guru dengan menerapkan pembelajaran dengan Direct Instruction.

\section{Refleksi}

Dalam pelaksanaan kegiatan belajar mengajar diperoleh informasi dari hasil pengamatan sebagai berikut: memotivasi siswa dan dalam menyampaikan tujuan pembelajaran
1) Guru kurang maksimal dalam
2) Guru kurang maksimal dalam pengelolaan waktu
3) Siswa kurang aktif selama pembelajaran berlangsung

\section{Refisi}

Pelaksanaan kegiatan belajar mengajar pada siklus I ini masih terdapat kekurangan, sehingga perlu adanya revisi untuk dilakukan pada siklus berikutnya.

1) Guru perlu lebih terampil dalam memotivasi siswa dan lebih jelas dalam menyampaikan tujuan pembelajaran. Dimana siswa diajak untuk terlibat langsung dalam setiap kegiatan yang akan dilakukan.

2) Guru perlu mendistribusikan waktu secara baik dengan menambahkan informasi-informasi yang dirasa perlu dan memberi catatan.

3) Guru harus lebih terampil dan bersemangat dalam memotivasi siswa sehingga siswa bisa lebih antusias.

\section{Siklus II \\ Tahap perencanaan}

Pada tahap ini peneliti mempersiapkan perangkat pembelajaran yang terdiri dari rencana pelajaran 2, soal tes formatif 2 dan alat-alat pengajaran yang mendukung.

\section{Tahap kegiatan dan pelaksanaan}

Pelaksanaan kegiatan belajar mengajar untuk siklus II dilaksanakan pada tanggal 2 April 2019 di Kelas VII.9 dengan jumlah siswa 32 siswa. Dalam hal ini peneliti bertindak sebagai pengajar. Adapun proses belajar mengajar mengacu pada rencana pelajaran dengan memperhatikan revisi pada siklus I, sehingga kesalahan atau kekurangan pada siklus I tidak terulang lagi pada siklus II. Pengamatan (observasi) dilaksanakan bersamaan dengan pelaksanaan belajar mengajar.

Pada akhir proses belajar mengajar siswa diberi tes formatif II dengan tujuan untuk mengetahui tingkat keberhasilan siswa 
dalam proses belajar mengajar yang telah dilakukan. Instrumen yang digunakan adalah tes formatif II. Adapun data hasil penelitian pada siklus II adalah sebagai berikut.

Dari pengelolaan pembelajaran, tanpak aspek-aspek yang diamati pada kegiatan belajar mengajar (siklus II) yang dilaksanakn oleh guru dengan menerapkan metode pembelajarn Direct Instruction mendapatkan penilaian yang cukup baik dari pengamat. Maksudnya dari seluruh penilaian tidak terdapat nilai kurang. Namun demikian penilaian tesebut belum merupakan hasil yang optimal, untuk itu ada beberapa aspek yang perlu mendapatkan perhatian untuk penyempurnaan penerapan pembelajaran selanjutnya. Aspek-aspek tersebut adalah memotivasi siswa, membimbing siswa merumuskan kesimpulan/ menemukan konsep, dan pengelolaan waktu.

Dengan penyempurnaan aspek-aspek I atas alam penerapan metode pembelajarn Direct intruction diharapkan siswa dapat menyimpulkan apa yang telah mereka pelajari dan mengemukakan pendapatnya sehingga mereka akan lebih memahami tentang apa ynag telah mereka lakukan

Dari analisa data diperoleh nilai ratarata prestasi belajar siswa adalah 74 dan ketuntasan belajar mencapai $83 \%$ atau ada 27 siswa dari 32 siswa sudah tuntas belajar. Hasil ini menunjukkan bahwa pada siklus II ini ketuntasan belajar secara klasikal telah mengalami peningkatan sedikit lebih baik dari siklus I. Adanya peningkatan kemampuan berbicara siswa ini karena setelah guru menginformasikan bahwa setiap akhir pelajaran akan selalu diadakan tes sehingga pada pertemuan berikutnya siswa lebih termotivasi untuk belajar. Selain itu siswa juga sudah mulai mengerti apa yang dimaksudkan dan diinginkan guru dengan menerapkan pembelajaran dengan Direct Instruction .

\section{Refleksi}

Dalam pelaksanaan kegiatan belajar diperoleh informasi dari hasil pengamatan sebagai berikut. Memotivasi siswa, Membimbing siswa merumuskan kesimpulan/menemukan konsep,Pengelolaan waktu

\section{Revisi Rancangan}

Pelaksanaan kegiatan belajar pada siklus II ini masih terdapat kekurangankekurangan. Maka perlu adanya revisi untuk dilaksanakan pada siklus II antara lain:

Guru dalam memotivasi siswa hendaknya dapat membuat siswa lebih termotivasi selama proses belajar mengajar berlangsung.

Guru harus lebih dekat dengan siswa sehingga tidak ada perasaan takut dalam diri siswa baik untuk mengemukakan pendapat atau bertanya.

Guru harus lebih sabar dalam membimbing siswa merumuskan kesimpulan/menemukan konsep.

1) Guru harus mendistribusikan waktu secara baik sehingga kegiatan pembelajaran dapat berjalan sesuai dengan yang diharapkan.

2) Guru sebaiknya menambah lebih banyak contoh soal dan memberi soalsoal latihan pada siswa untuk dikerjakan pada setiap kegiatan belajar mengajar.

\section{Siklus III}

Tahap perencanaan

Pada tahap ini peneliti mempersiapkan perangkat pembelajaran yang terdiri dari rencana pelajaran 3 , soal tes formatif 3 dan alat-alat pengajaran yang mendukung.

\section{Tahap kegiatan dan pengamatan}

Pelaksanaan kegiatan belajar mengajar untuk siklus III dilaksanakan pada tanggal 14 April 2019 di Kelas VII.9 dengan jumlah siswa 32 siswa. Dalam hal ini peneliti bertindak sebagai pengajar. Adapun proses belajar mengajar mengacu pada rencana pelajaran dengan memperhatikan revisi pada siklus II, sehingga kesalahan atau kekurangan pada siklus II tidak terulang lagi pada siklus III. Pengamatan (observasi) dilaksanakan bersamaan dengan pelaksanaan belajar mengajar.

Pada akhir proses belajar mengajar siswa diberi tes formatif III dengan tujuan untuk mengetahui tingkat keberhasilan siswa dalam proses belajar mengajar yang telah dilakukan. Instrumen yang digunakan adalah tes formatif III. Adapun data hasil penelitian pada siklus III adalah sebagai berikut. 
Dari pengolahan data pengelolaan pembelajaran, dapat dilihat aspek-aspek yang diamati pada kegiatan belajar mengajar (siklus III) yang dilaksanakan oleh guru dengan menerapkan metode pembelajaran kooperatif model Direct intruction mendapatkan penilaian cukup baik dari pengamat adalah memotivasi siswa, membimbing siswa merumuskan kesimpulan/menemukan konsep, dan pengelolaan waktu.

Berdasarkan hasil analisa data diperoleh nilai rata-rata tes formatif sebesar 77 dan dari 32 siswa telah tuntas sebanyak 31 siswa dan 1 siswa belum mencapai ketuntasan belajar. Maka secara klasikal ketuntasan belajar yang telah tercapai sebesar $95 \%$ (termasuk kategori tuntas). Hasil pada siklus III ini mengalami peningkatan lebih baik dari siklus II. Adanya peningkatan kemampuan berbicara pada siklus III ini dipengaruhi oleh adanya peningkatan kemampuan guru dalam menerapkan pembelajaran dengan Direct Instruction sehingga siswa menjadi lebih terbiasa dengan pembelajaran seperti ini sehingga siswa lebih mudah dalam memahami materi yang telah diberikan.

\section{Refleksi}

Pada tahap ini akan dikaji apa yang telah terlaksana dengan baik maupun yang masih kurang baik dalam proses belajar mengajar dengan penerapan pembelajaran dengan Direct Instruction . Dari data-data yang telah diperoleh dapat diuraikan sebagai berikut:

1) Selama proses belajar mengajar guru telah melaksanakan semua pembelajaran dengan baik. Meskipun ada beberapa aspek yang belum sempurna, tetapi persentase pelaksanaannya untuk masing-masing aspek cukup besar.

2) Berdasarkan data hasil pengamatan diketahui bahwa siswa aktif selama proses belajar berlangsung.

3) Kekurangan pada siklus-siklus sebelumnya sudah mengalami perbaikan dan peningkatan sehingga menjadi lebih baik.

4) Kemampuan berbicara siswa pada siklus III mencapai ketuntasan.

\section{Revisi Pelaksanaan}

Pada siklus III guru telah menerapkan pembelajaran dengan Direct Instruction dengan baik dan dilihat dari aktivitas siswa serta kemampuan berbicara siswa pelaksanaan proses belajar mengajar sudah berjalan dengan baik. Maka tidak diperlukan revisi terlalu banyak, tetapi yang perlu diperhatikan untuk tindakan selanjutnya adalah memaksimalkan dan mempertahankan apa yang telah ada dengan tujuan agar pada pelaksanaan proses belajar mengajar selanjutnya penerapan model pengajaran Direct Instruction dapat meningkatkan proses belajar mengajar sehingga tujuan pembelajaran dapat tercapai.

\section{Pembahasan}

\section{Ketuntasan Kemampuan berbicara Siswa}

Melalui hasil penelitian ini menunjukkan bahwa pembelajaran dengan Direct Instruction memiliki dampak positif dalam meningkatkan prestasi belajar siswa. Hal ini dapat dilihat dari semakin mantapnya pemahaman siswa terhadap materi yang disampaikan guru (ketuntasan belajar meningkat dari siklus I, II, dan III) yaitu masing-masing 73\%, 83\%, dan 95\%. Pada siklus III ketuntasan belajar siswa secara klasikal telah tercapai.

\section{Kemampuan Guru dalam Mengelola Pembelajaran}

Berdasarkan analisis data, diperoleh aktivitas siswa dalam proses belajar mengajar dengan menerapkan model pengajaran Direct Instruction dalam setiap siklus mengalami peningkatan. Hal ini berdampak positif terhadap prestasi belajar siswa yaitu dapat ditunjukkan dengan meningkatnya nilai ratarata siswa pad setiap siklus yang terus mengalami peningkatan.

\section{Aktivitas Siswa Dalam Pembelajaran}

Berdasarkan analisis data, diperoleh aktivitas siswa dalam proses pembelajaran Bahasa Indonesia dengan model pengajaran Direct Instruction yang paling dominan adalah, mendengarkan/memperhatikan penjelasan guru, dan diskusi antar siswa /antara siswa dengan guru. Jadi dapat dikatakan bahwa aktivitas siswa dapat dikategorikan aktif.

Sedangkan untuk aktivitas guru selama pembelajaran telah melaksanakan 
langkah-langkah kegiatan belajar mengajar dengan menerapkan pengajaran konstekstual model pengajaran berbasis masalah dengan baik. Hal ini terlihat dari aktivitas guru yang muncul di antaranya aktivitas membimbing dan mengamati siswa dalam menemukan konsep, menjelaskan materi yang sulit, memberi umpan balik/evaluasi/tanya jawab dimana prosentase untuk aktivitas di atas cukup besar.

\section{Simpulan}

Berdasarkan hasil penelitian yang telah dipaparkan selama tiga siklus, hasil seluruh pembahasan serta analisis yang telah dilakukan dapat disimpulkan sebagai berikut:

1. Model pengajaran Metode Pembelajaran Direct Instruction dapat meningkatkan kualitas pembelajaran Ilmu Pengetahuan Alam.

2. Pembelajaran dengan Metode Pembelajaran Direct Instruction memiliki dampak positif dalam meningkatkan prestasi belajar siswa yang ditandai dengan peningkatan ketuntasan belajar siswa dalam setiap siklus, yaitu siklus I (73\%,), siklus II (83\%), siklus III (95\%).

3. Model pengajaran Metode Pembelajaran Direct Instruction dapat menjadikan siswa merasa dirinya mendapat perhatian dan kesempatan untuk menyampaikan pendapat, gagasan, ide dan pertanyaan.

4. Siswa dapat bekerja secara mandiri maupun kelompok, serta mampu mempertanggungjawabkan segala tugas individu maupun kelompok.

5. Penerapan pembelajaran dengan Metode Pembelajaran Direct Instruction mempunyai pengaruh positif, yaitu dapat meningkatkan motivasi belajar siswa.Saran

Dari hasil penelitian yang diperoleh dari uraian sebelumnya agar proses belajar mengajar Ilmu Pengetahuan Alam lebih efektif dan lebih memberikan hasil yang optimal bagi siswa, maka disampaikan saran sebagai berikut:

1. Untuk melaksanakan model pengajaran Metode Pembelajaran Direct Instruction memerlukan persiapan yang cukup matang, sehingga guru harus mampu menentukan atau memilih topik yang benar-benar bisa diterapkan dengan pembelajaran dengan Metode Pembelajaran Direct Instruction dalam proses belajar mengajar sehingga diperoleh hasil yang optimal.

2. Dalam rangka meningkatkan prestasi belajar siswa, guru hendaknya lebih sering melatih siswa dengan berbagai metode pengajaran, walau dalam taraf yang sederhana, dimana siswa nantinya dapat menemukan pengetahuan baru, memperoleh konsep dan keterampilan, sehingga siswa berhasil atau mampu memecahkan masalah-masalah yang dihadapinya.

3. Perlu adanya penelitian yang lebih lanjut, karena hasil penelitian ini hanya dilakukan di Kelas VII.9 tahun pelajaran 2018/2019.

4. Untuk penelitian yang serupa hendaknya dilakukan perbaikanperbaikan agar diperoleh hasil yang lebih baik.

\section{DAFTAR PUSTAKA}

Alwi, H. (2002). Kamus Besar Bahasa Indonesia. Jakarta: Balai Pustaka.

Arends, R.I. (2008). Learning To Teach (Belajar Untuk Mengajar). Yogyakarta: Pelajar Pustaka.

Arikunto,S. (2006). Prosedur Penelitian Suatu Pendekatan Praktek. (Edisi Revisi II). Jakarta: Rineka Cipta. (2006). Dasar-Dasar Evaluasi Pendidikan. (Edisi Revisi). Jakarta: Bumi aksara. (2016). Prosedur Penelitian Suatu Pendekatan Praktek. (Edisi Revisi 2016). Jakarta: Rineka Cipta.

Guilford ,J.P.(1979). Psychometric Methods. Tata McGraw-Hill Publishing Company Limited. [online] tersedia :

http://datastats.blogspot.com/2008/08/teorireliabilitas_03.html [23 oktober 2016].

Hamalik, O. (2003). Proses Belajar Mengajar. Jakarta: Bumi Aksara. 
Juhana, O. dan Suratman, M. (2000). Menggambar Teknik Mesin. Bandung: Pustaka Grafika.

Joyce, B., Weil, M., dan Calhoun, E. (2009). Model of Teaching (Model-Model Pengajaran). Yogyakarta: Pustaka Pelajar.

Kardi, S. dan Nur, M. (2001). Pengajaran Langsung. Surabaya: UnesaUniversity Press.

Karno To. (1996). Mengenal Analisis Test. Bandung: Jurusan Psikologi Pendidikan dan Bimbingan. FIP. IKIP.

Nugraha, R. (2008). Pengaruh Model Pembelajaran Kontekstual Berbasis Praktikum Terhadap Pemahaman Konsep Mata Diklat Gambar Teknik. Skripsi FPTK UPI Bandung: tidak diterbitkan.

Makmun, A.S. (1997). Psikologi Kependidikan. Bandung: Remaja Rosdakarya.

Sagala, S. (2007). Konsep Dan Makna Pembelajaran Untuk Membantu Memecahkan Problematika Belajar dan Mengajar. Bandung: Alfabeta.

Sanjaya, W. (2009). Strategi Pembelajaran Berorientasi Standar Proses Pendidikan. Jakarta: Kencana.

Sato, T.G. (1999). Menggambar Mesin. Jakarta : PT. Pranadya Paramita.

Siregar, S. (2004). Statistik Terapan. Jakarta: Grasindo.

Slameto. (2003). Belajar dan Faktor-Faktor yang Mempengaruhinya (Edisi Revisi). Jakarta: Rineka Cipta.

Sudjana. (1996). Metoda Statistika. (Edisi ke6). Bandung : Tarsito.

Sudjana, N. dan Ibrahim. (2009). Penelitian dan Penilaian Pendidikan. Bandung: Sinar Baru.

Sugiyono. (2009). Metode Penelitian Pendidikan Pendekatan Kuantitatif, Kualitatif, dan R \& D. Bandung: Alfabeta.

Susilana, R. (2006). Kurikulum \& Pembelajaran. Bandung: UPI.

Trianto. (2007). Model-Model Pembelajaran Inovatif

Berorientasi
Konstruktivistik. Jakarta: Prestasi Pustaka Publisher.

Universitas Pendidikan Indonesia. (2016). Pedoman Penulisan Karya Ilmiah. Bandung: UPI

Yamin, Martinis. (2009). Profesionalisasi Guru \& Implementasi. Jakarta: Gaung Persada Press. 